\title{
Protecting Human Rights and Constitutional Law in Bicameral
}

\section{Systems}

\author{
Mohammadreza Baharestanfar ${ }^{1} \&$ Seyed Mohammad Hashemi ${ }^{1}$ \\ ${ }^{1}$ Department of Public and International Law, Science and Research Branch, Islamic Azad University, Tehran, \\ Iran
}

Correspondence: Seyed Mohammad Hashemi, Department of Public and International Law, Science and Research Branch, Islamic Azad University, Tehran, Iran. E-mail: smohammadhashemi95@gmail.com

Received: December 20, 2016

Accepted: January 19, 2017 Online Published: January 9, 2018

doi:10.5539/jpl.v11n1p17

URL: https://doi.org/10.5539/jpl.v11n1p17

\begin{abstract}
Background and objective: The second legislative chamber has played different roles and functions since its formation in ancient Rome and Greece. The philosophy behind the presence of this chamber (either in Federal systems or unitary systems) was a matter of controversy between its proponents and critics. There are more than 78 countries with two legislative chambers in the world. Protecting constitutional law and human rights are two notable functions of the second chambers. Research method: This paper used the descriptive-analytical method. The methods used by some second chambers are discussed as an example. Results (findings): how a second chamber can be considered as the scout of constitutional law and protector of human rights with regard to their normative behavior depends on the structure of the constitutional law. The role of the second chamber in protecting constitutional law is manifested in several forms: coinciding the bills and laws with constitutional law, amending and revising the constitutional law, vetoing or suspending bill a general appointments. Second chambers have several solutions including establishing the human rights committee with various duties. Therefore, these two criteria seem to be useful in order to measure the extent of democracy. Conclusion: A powerful second chambers are needed to make decisions, have the authority to amend the laws, and to have effect on the politics to realize human rights and protection of Constitutional law. It can also act as a human rights watch with regard to the nature of the norms of human rights.
\end{abstract}

Keywords: bicameral system, constitutional law, human rights, second legislative chambers

\section{Introduction}

Historically, the Senate dates back to ancient Rome and it has always been accompanied by aristocracy. The nobles who had special privileges avoided blindly obeying the kings, and at times held similar power as the king's. The Senate either was transformed to a second chamber or its nature was manipulated and was taken away from the rationale behind its presence over the history.

Since the early days of the constitutional law movement and parliament establishment, there have been controversies over the structure and combination of the legislative organization. With regard to the remarkable function of the political realities and historical and sociological backgrounds, the formation of the bicameral system is worthy of consideration (Ranjbar, 2004). Having bicameral or unicameral systems and the structure of the second chamber, the role and its significance mainly results from legal arguments. The bicameral system in federal governmental systems or in countries with parliamentary or presidential systems is due to policy and social, legal, political and historical requirements of the country.

It is no easy task to identify the countries that have bicameral systems. The antiparliamentary unit of Westminster identified 189 countries that have a national legislature. Seventy eight countries have a bicameral system and 111 countries have a unicameral system (House of Lords, 2014).

Federal countries view the number of the chambers from the structural requirements and the discussions takes on technical significance. The principle of the bicameral system in the federal countries is related to the tendency to protect their cultural, religious or language diversities according to political considerations. These two chambers fulfill the opposite tendencies to unity in diversity. Therefore, it turns out to be a criterion. However, in nonfederal countries, there is no technical justification for bicameral system. In countries like France and Britain, 
the second chamber (upper house) has been formed due to the realities of the society and has a theoretical base and logic. For example, the English system follows political tradition and norms based on long-standing aristocracy which had held as much power as the king (Ranjbar, 2004).

Other evidence is needed to justify bicameral systems in unicameral countries. Although right-wing parties favor bicameral systems and left-wing parties have been against the second chamber, we have to consider the second chamber as the result of political partialities. The advocates of the second chamber consider it as a necessary organization with regard to the interactions between the executive and legislative power and argue that one parliament can change or collapse government with regard to the political accountability of the executive power to the parliament due to extremism and internal emotions of the parliament. This may not be in favor of the society. Finally, it may result in improper dominance of the legislative power over the executive power. Therefore, there has to be another chamber to keep the ideal balance between these powers.

A Stewart Mill states, arguments will be sound if the proportion of the? Number of members of each chamber is not the same in two chambers, and if one party holds the majority in one chamber, it is not the dominant party in the other chamber. So, as the two chamber members are elected by the people, there is no need for both of them (Mill, 1990).

With regard to historical realities, the first chamber is the representative of the transient decisions made by the public, and since the members are young and emotional, harshly approval of the laws is inevitable. Consequently, there should be another second chamber with politicians holding different qualifications to solve the deficiencies of the democratic chamber. This is the rationale behind the presence of the second chamber in the democratic systems i.e. it gains its legitimacy by improving the law quality.

In a bicameral system, chamber and the representatives with full authority and freedom negotiate, perform their duties and formulate the laws. In this view, the approved acts of parliament are evaluated by using the knowledge and experience of the society in order to prevent the chamber from approving imperfect or ineffective laws. Montesquieu considers the two chambers necessary for balance of power. So, presence of the experienced men [and women] and scholars in the process of legislating is highly necessary. This important matter is realized by establishing two chambers consisting of experienced members and scholars. The second chamber represents the thought of the old and experienced people against the youths. Members may be elected or appointed and sometime there is a mixture of them. The mixed chamber (both elective and appointive) seems to be more justifiable. It means that people play role in electing the elites of the chamber and make way for the knowledgeable and experienced people to directly go to Senate (Rasekh, 2005). Permanent Lords are usually active politicians who are more active when approving the laws. An appointive second chamber is not able to play the role of a powerful chamber in the democratic political systems (Olsun, 2003).

Philip Norton made a report in 2004, based on which, one third of the world legislative chambers and two third of the highly fully democratic countries have bicameral systems. Therefore, bicameral system is an established organization within the significant legislative systems of the world and each country choose to have this system based on its requirements. The structure of the legislative power is based on the characteristics and conditions which are formed across the time and history. They are rooted in the political, cultural, economic and social affairs and mostly don't originate from the laws (Gorji Azandaryani, 2015).

One duty of the upper chamber is to protect the constitutional law. The main objectives of the upper chambers have two aspects: as the representative of one social class or conservative interests and representative of a state in federal systems. In both of them, the upper chamber naturally plays a special role to protect governmental (public) organizations against the political and immediate actions taken by lower chamber.

The main question this paper answers is: to what extent do upper houses play in protecting constitutional law and fundamental liberties and does this matter depend on which matters in public rights? This is unclear.

With regard to human rights issues and fundamental liberties, we may say, the distinguishing feature of a democratic society is to protect human rights. But the main concern of these liberal societies is the manner of supporting the human rights and which organization is in charge of its protection. Does the judiciary power or legislative power give preference in citizens' rights? Are multi cameral legislative chambers necessary or not? Do they contribute to ideal governance or not?

Each country may give a differ answer to these questions. They may propose different models for their response. The best model called democratic discourse states that two organizations of legislature and legislative powers interact with each other and control the protection of human rights in their mutual relationships. In this model every organization is in need of the other and they cooperate with each other (Norton, 2013). 
Since one of the remarkable features of the bicameral systems is its stability and permanency, the majority in the legislative chamber in democratic governments is bicameral or multi cameral and the second chamber plays an important role in protecting the constitutional law as the constitutional watchdog and increases the parliamentary democracy (Reidy \& Russell, 1999).

Lots of researches have been done on second chambers and researchers and lawyers have discussed the rationale behind its existence and its various performances. But a comprehensive analysis about its function in the various systems (either generated from West Minister or other systems) is new.

After discussing the rationale behind existence of the second chamber, this paper discusses the nature of the human rights and constitutional law norms. Then it analyzes the role of the second chamber in protecting constitutional law with an international view as well as maximum protection of the human rights with investigating some of the second chambers.

\section{The Philosophy behind the Existence of the Second Legislative Chamber in Federal and Unitary Systems}

It is a reality that first chambers have not been effective fulfilling all needs of the government for democracy, rule of law and comprehensive protection of the human rights. So, the need for the second chamber has been confirmed by many schools of thought by providing justifiable evidence. But the arguments and logical evidences made by opposition groups have been logical at times. Firstly, we will discuss the most significant necessities and philosophy and rational behind the second chamber from proponents of this system and compare it in unitary and federal systems.

The difference in the unicameral and bicameral systems is related to the political background of the systems and is not related to legal aspects. However, some lawyers apparently tried to apply a legal identity to it and make legal reasoning for it. For example, the parliamentary chamber of the England was established just due to the political and historical incidents and there is no valid legal reason to justify this bicameralism. However, due to effects of other European countries as well as the effect of the England on constitutional rights of the Asian, American and African countries, the bicameral parliamentary system has also adopted in many countries. The tendency to adopt bicameral system spread following the World War. Many countries favor of bicameral systems (Ghazi, 2011).

Considering the complications of the public rights, it is needed to control and keep balance in this field. But it is also possible that another organization (other than second chamber) undertake this important responsibility. For example, the judiciary power may have better control than parliamentary chambers. But it cannot be taken for granted. So, the role of the second chamber will be remarkable, especially in modern societies with more complicated role of the government.

Democratic governments may not be able to fulfill their aims just by using the public powers. A chamber that considers different interests (either explicitly or implicitly), can play a crucial role in mobilizing the supports (Donald shell, 2001).

Bicameral systems are based on two principles. One is based on the territory, social groups, ethnic groups, language; race and so on, like those in the United States and India. The other is based on historical, cultural and traditional background of the societies which make some groups as upper groups including upper social groups of lords, aristocrats, clergies, etc. each of them propose a different model of bicameralism (Congleton, 2002).

Charles de Montesquieu, (date) French theoretician, is considered to be one of the most effective theory makers of the dual legislative chamber; he considers the second chambers as the portion of the lords and nobles in legislating in his book "Spirit of Laws". Following the Charles de Montesquieu suggestion, many constitutional law formulators accepted the bicameral system of the parliament and stipulated it in the constitutional law.

The elite-oriented approach considers the fear from tyranny of the masses as a justification for establishing the second chamber (Gorji Azandriani, 2015). But for the new democratic approach the rationale behind this system is to improve the surveillance,balance the system and improve the quality of the legislating, political legitimacy and stability (Gorji Azandriani, 2015). The lower chamber was manifesting a sign of social democratic elements. But upper chamber is the sign of aristocracy. Theoretically, the combination of the political representativeness and lawful efficiency ensures that will not be corrupted under the shadow of an upper tyrant group.

The lower chamber is the sign of change and dynamisms, because it reflects the ideas of the common people who are in favor of new experiences and revolutions in the social relationships. The laws approved by this chamber properly indicate this matter. The second house is the representative of expediency, logic and counsel. They are indicative of reasoning versus hasty decision making, elites versus masses, the vote of old people 
versus will of youths (Tabatabaei Motmani, 2007). Contrary to the traditional approaches, nowadays the tendency toward the second chamber is not for satisfying elites and upper classes, but it is a technique to remedy the defects of the acts approved by first chamber.

The proponents of the second chamber propose another strong reason for its necessity, and say it controls and balances power. In this way, the senate can limit the government by different means. For example, it can ensure that the civil options and human rights are protected and executive power cannot threat? The minority of the society or the society as a whole.

Another reason for necessity of second chamber is that this chamber prevents? Who from enacting hasty laws; they reflect the long-term ideas of the voters and act as a brake in impeding the lower chambers who has won the elections.

Finally, proponents of the second bicameral systems consider it as necessary particularly in parliamentary systems, because they believe that lack of a second chamber, makes the executive power a weak organization against the legislative power and it loses its initiative due to the power of the legislature. The executive power tries to act according to parliament's wishes, because parliament can collapse it. Additionally, the excessive change in the cabinet impedes the countries' development and civilization. It is crystal clear that this incident is not beneficial $t$ countries interests.

The other reasons made by proponents of the bicameral systems include; controlling the power of second chamber, supervision and auditing the performance of the executive power, revealing the deficiencies of the government and so on.

These reasons and arguments may vary depending on nations' political systems. The federal countries with bicameral systems believe that a parliament with two chambers can aptly guarantee the democracy. These countries are established based on two principles of unity and pluralism. So a bicameral system can reflect the unity in diversity much better.

Second chambers of the federal countries depict the tendency for pluralism and maintaining the identity and personality of the governments. The majority of the politicians and constitutional law formulators in the federal countries accept and confirm this law. A bicameral system is realized provided that: A) the representatives of the two chambers are equal in number B): the equal authority of two chambers in both legislation and supervising on executive power's actions (Ghazi, 2001). The bicameral system of the some federal countries like United States, Swiss, Germany, Austria and India roughly confirms? What? Similar to which two countries? To two above-mentioned countries. Some other countries' systems do not meet conditions such as ....

The number of chambers is one of the controversial subjects in the constitutional law of the unitary countries. The conflict between the proponents of the bicameral system and unicameral one goes on. This conflict used to have legal aspect in the past but takes on political form at now. Right wing parties like conservative and liberals are in favor of systems with two chamber (bilateral) and left wing parties like communists and socialists are component of the systems that have one parliament (Ghazi, 2001).

Finally, it is worth noting that the way of electing the members of the second chamber have great effects on their role and function. There exist several ways for determining second chamber members including: appointment by the government, succession (by inheritance), indirect election or direct election. The representatives who are the permanent members of the House of Lords in England or Italian Senate should have social and scientific qualifications. Where they are directly elected, their term of office is longer than first chamber, for example, a U.S Senator's term of office is six years. Some of the second chambers are appointed by executive power, for example Canada's Senate.

\section{Nature of Human Right's Norms and Constitutional Laws}

Human rights are universal as specified in article 1 of the Universal Declaration of Human Rights and other human right documents. Universality of the human rights means that everyone is entitled to benefit from these rights, no matter who rules the country. Therefore, we may say ambiguity in the constitutional law and domestic common laws have no effect on the principle of citizens' rights to benefit from human rights.

With role that second chamber plays, bicameral systems are more effective on protecting human rights and improving its conditions.

The fundamental concept of limiting the authority of the rulers by constitutional law is based on the basic principle of individual freedom; the logical result of this system is that the ruler's has no guardianship on people. The primary principles are people's guardianship over themselves and freedom. The rule of law principle is also 
based on the ruler's lack of jurisdiction and competence. So, the concept of constitutionalism generates from the constitutional principle of the freedom. Actually, the constitutional law is an organized plan to transfer a fraction of people's freedom to the government. Constitutional law has bilateral function. It both limits the freedom of the people and guarantees it. On the one hand, constitutional law confirms the jurisdiction and authority of the rulers, on the other hand, it stipulates the limitations of the government officials that results in ensuring people's freedom. Limited governance and establishing constitutional freedoms (and guarantee) is the ultimate goal of the constitutionalism (Ghari, Seyyed fatemi, 2011).

The function of the constitutional law is to control power and prevent despotism of the rulers. It also should guarantee civil rights. Common laws also play an important role in ensuring human rights due to their broader and more practical usage. The control system exerted by upper chambers in the bicameral systems is another way to control laws in terms of human rights. If we assume that the major and significant duty of constitutional law is to guarantee civil rights and provide an overall framework to guarantee the fundamental rights and freedoms of the people, it will lead to formulating a legal mechanism in order to control the laws in terms of human rights (Ghari Seyyed Fatemi, 2011).

For example, England is unique in terms of amending and changing the constitutional law or limiting the constitutional freedoms like that of common laws. Additionally, England has a powerful executive and legislative system. It empowers the government to perform its intended projects. So, parliament has to supervise the executive departments. It should also explore the proposals offered for manipulation and amendment in the constitutional law and the violation of human rights. Consequently, protecting the constitutional law is a duty of upper chambers. The human rights' laws approved in the municipal laws also vest another responsibility in parliament and government to protect human rights.

Therefore, by considering the nature of the human rights' norms and constitutional laws, we will discuss the role of the second chamber in effective and comprehensive protection of these norms and regulations in the following sections:

\section{The Role of the Second Chamber in Protecting Constitutional Law from an International Perspective}

The upper chamber has special authorities in many countries in order to be able to protect constitutional law. The domain and scope of these authorities is dependent on the structure of the constitutional law. For example, in federal systems like Germany, Canada and South Africa the provincial or state chamber have some authorities and powers in common. However, the upper chambers act as a representative organization for various departments of the federation. In centralized governments, upper chambers hold more power to protect the constitutional law by legislation.

Every second chamber including those that are not professional ethic powerful enough have a special responsibility to protect the constitutional law. This responsibility stems from the purpose and position of the second chamber. Upper chambers act as a deputy to protect the interests of the government or as the people's representative in federal systems. Since upper chambers do not depend on the parties and have more autonomy, compared to lower chamber, they can appropriately perform their duties to supervise and impede hasty and political activities of the lower chambers. Some scholars believe upper chambers may fulfill their duties in two ways: firstly, by establishing protective systems to be applied at time of constitution's changes. Secondly, by performing their supervisory duties in order to ensure that government execute its duties within the framework of the constitutional law. The House of Lords may perform some actions related to legislature and modification of the constitutional law.

To sum up, the role constitutional law may be performed in several ways: to investigate the conformity of the bills and laws to constitutional law, to revise and amend constitutional law to veto and suspend the bills and public appointments.

\subsection{To Investigate the Conformity of the Bills and Laws to Constitutional Law}

Generally, every rule should conform to the constitutional laws. Every law that is approved but is against the constitutional law should be impeded. This matter generates from the superiority of the constitutional law over other common laws. Approving laws that are against constitutional laws makes the constitutional law susceptible to the change and the nation's stability is not achieved. The constitutional law has been accepted to be the mother law and every ongoing regulation should conform to the constitutional law. So, there has to be a competent organization which controls this consistency (Madani, 2009).

Some second chambers have the power to challenge the bills that do not conform to the constitutional laws. They achieve this goal, by referring the bills to the constitutional law court, if the bills violate some regulations 
stipulated in the constitutional law. For example, there are 6 ways to refer the bills to the constitutional law court and a group consisting of 50 senators in Spain can refer a bill to the constitutional law court. In parliaments, the opposition party entitled with this right and can oppose the bills due to violation of the constitutional law (Russell, 2001).

\subsection{Amendment, Revision and Interpretation of the Constitutional Law}

Constitutional law like every other law is accountable to certain social and political conditions and requirements. When these requirements and conditions change, the constitutional law has to be revised and be conformed to the social needs. Revising the constitutional law is a political matter and the solutions for its manipulation has been stipulated and predicted in the constitutional law of all countries (Madani, 2009).

Bills concerning the constitutional law amendment face with more difficulties for approval than the common laws in all countries and include special powers for the upper chambers. In all cases it vests special power in House of Lords. The upper chamber is entitled to veto right I order to veto the bills concerning constitutional law amendments or they may be subject to automatic referendum. In order to approve these constitutional law amendments, many countries require majority of the votes are required. It requires an absolute majority in Italy, the consent of two this if the parliament member's is required in Germany. In Spain, 15days after enacting the bills, $1 / 10^{\text {th }}$ of the members can request to hold a referendum for the approved bill of the constitutional law (Russell, 2001).

In the United States, the revision of the constitutional law can be approved by $2 / 3^{\text {rd }}$ of the whole members in each of the chamber or it can be proposed by $2 / 3^{\text {rd }}$ legislative power of the states.

The congress plays more important role and has the initiative and power to determine the qualified peoples of the states in the long process of revising the constitutional law (Boushehri, 2011).The Senate may act as a real and standing hindrance against making changes (amendments) in the constitutional law in countries such as Germany, French, Italy and Spain.

The interpretation of the constitutional law is performed if the principles of the constitutional law are not clear and explicit enough (Madani, 2009). The department for interpretation is mostly assigned by Senate.

\subsection{To Veto and Suspend the Bills}

Second chambers mainly play a powerful function in the field of constitutional law. Even if they are not more powerful than the first chamber, they can show their power by exerting their effect on enacting the bills. Even in the conservative parliaments the veto power vested in upper chambers seems to be useful. Ireland and Spain Senate has the power to suspend the bills for a specified period of time. The Senate has the right to veto the bills.

\subsection{Another Way to Protect the Constitutional Law in the Bicameral System Countries Is Establishing a Court to} Protect the Constitutional Law

This court may be Constitutional Law Court or the Arbitral Tribunal. In many countries like France, Germany, Italy, Ireland and Australia, Constitutional Law Court is in charge of revising to protect the Constitutional Law. It is also in charge of settling the disputes related to the constitutional law (Russell, 2001).

The disputes raised on the consistency of the new laws with constitutional law depend on the proceedings taken by constitutional law court (Italy and Austria) or a final court who have the jurisdiction to entertain the issues related to the constitutional law (Ireland and Japan). The decisions made by this court are considered to be binding and final decision. There are special entities to settle these disputes in some other countries. Referral of these kinds of matters to such a court is done both before and after approving them.

The relationship between the parliament and that of the organization in charge of revising constitutional law is performed by two ways: firstly; the upper chamber has the power to refer the disputes and issues to constitutional law court. The characteristics that various referral methods have in common are as following:

The referral is done by a specified number of the parliament members or the speaker of the parliament.

In Germany, the second chamber as the representative of the government can request the Constitutional Law Court to issue an order of consistency with the constitutional law, only if the dispute rises on the legal jurisdiction of the states and federations. In Poland, the President of the Senate can request making a judgment between governmental organs only in one case (Reidy and Russell, 1999).

The other way by which second chambers and its members can protect constitutional law is by engaging with public appointments like appointing the members of the constitutional law. The best example for this case is France, where the Senate President appoints 3 members out of 9 members of the constitutional law council. In 
some countries like Russia and U.S, the supreme judiciary appointments are done only by Senate (House of Lords). In other countries, this duty is divided by two chambers (Russell, 2001).

The Bundesrat, Germany's upper chamber, seems to be more effective among the second chambers. Because it should necessarily confirm any amendment made in the constitutional law and it acts as mechanism to attract the protection of the German estates.

There are several ways for upper chambers to play a more significant role as a watchdog of constitutional law. The important of them is taking the responsibility for protecting human rights. Therefore, protecting human rights is just possible in the light of protecting constitutional law.

\section{Second Legislative Chamber and Maximum Protection of the Human Rights}

As mentioned earlier, we may protect constitutional law by two ways: firstly; by taking protective measures when changing the nature (principles) of the constitutional law and secondly by ensuring that the act of legislating performed by government is based on the constitutional law. Additionally, upper chambers play a significant role in executing and controlling over the execution of the human rights' laws and human rights' obligations.

The distinguishing feature of a democratic society is its protection from human rights. But the main concern of these liberal societies is the manner of supporting the human rights and which organization is in charge of its protection? The judiciary power or legislative power?

Each country may give its own different answer to these questions. They may propose different models for their response. The best model called democratic discourse states that two organizations of legislature and legislative powers interact with each other and control the protection of human rights in their mutual relationships. In this model every organization is in need of the other and they cooperate with each other (Norton, 2013).

In countries with a bicameral system, the upper chamber is the watchdog of the constitutional law. This issue has also effect on the protection of the human rights. Now, we want to explain how the protection is performed and how it works. Chamber establishes certain organs to protect the human rights and solve the problems of the human rights. The organs that exist in the upper chamber are very different, and with various rules, duties and scope of power. The most important organs of these kinds are human rights committees that exist in the second chamber and have a vast authority in human rights field. The most important acts taken by these organs are as following:

\subsection{Scrutinizing the Laws and Carrying out the Research}

In order to scrutinize the rules or the articles of the human right treaties of the government, the joint committees seem to perform the best function. For example, in Australia, Senate chamber has two permanent committees to investigate on bills, regulations and laws. Both committees act based on their party guidelines and benefit from experienced consultants to provide reports on the human rights violations. Senate Standing Committee on Regulations and Ordinances can reject the delegated legislations that are not in conformity with human right's criteria and Senate Committee for the Scrutiny of Bills informs Senate of the law violation. But the lower chamber has not such a power.

The House of Lords (Senate in some countries) can offer a proposal to the joint committees upon the chamber's stance against doing research on issues related to domestic human right's concerns and affairs related to foreign policies. Such powers are held by Romanian and Poland Senates, too.

\subsection{Promotion of the Laws}

The House of Lords may undertake the responsibility for promotion of the laws in order to undertake human rights' obligations. A committee consisting of house of the lords offers the legal bills that may contain some recommendations for legislation. There are some committees like the said committees in second chambers of other countries like Japan, Swiss, Check republic (Reidy \& Russell, 1999).

\subsection{Making Relationship with Human Rights'Bodies and Departments}

In addition to national bodies like human rights' commission, there is a special parliamentary body to protect human rights in some countries like citizens' rights commission of Poland. In South Africa, there are some independent bodies in order to promote the democracy. The bodies include two bodies with special human right missionary: department of Public Protector and Human Rights Commission. Then, there are two joint committees in the parliament under the constitutional law that are in charge of making relationship with the said bodies to perform human rights' policies (Reidy \& Russell, 1999). 
Since the parliament is the major protector of the human rights, we will discuss the role played by second chamber in protecting the human rights.

In this country, on the one hand a new system of laws are entered into common laws and it is based on this assumption that parliament has no intention to interfere or render it null and void, but on the other hand the parliament will remain as an upper organization to ensure the protection of people's rights. After approving the human rights' law enacted on 1998, all obligations of this Convention were taken into consideration in England's laws. It is worthy of noting that English judges played an important role in preparation and enactment of European Convention of Human Rights. This convention is the most important human right obligation in the Europe, in which all constitutional rights of human being has been taken into consideration.

The extent to which Convention articles manipulated the England laws was remarkable and the judges, who were obliged to observe the current traditional laws, had no choice but to learn the articles of the Convention. Consequently, the basic articles of the human rights law were not implemented by the October 2000. The effect of the convention on the judges was far from a simple law interpretation (Norton, 2013:4-7). Considering the articles of the European Convention of the Human Rights and its acceptance by legal system of England, no government official including the judges can act against the articles of this Convention. But parliament is in charge of monitoring the implementation of this law.

In 2001, a joint committee named joint committee of human rights begun his activities. This committee consisted of 12 members (each parliament 6 members) and a legal advisor provides advice for the committee.

The main duties of this committee includes scrutinizing all governmental bills in order to investigate their compatibility with human rights standards, examining the government reactions against court's judgments on human rights and controlling the England performance to be compatible with all of the international human rights obligations (Norton, 2013).

The effect of this committee is very remarkable on the performance of the three powers. The legislative power knowingly views the human right issues with more sensitivity. The relationship between the courts and government is more consistent. The actions taken by the committee has made public sectors to be prepared for law enforcement and establishing human right culture. Joint committee of human rights is in charge of supervising on both parliaments. However, it is the parliament that undertakes the main responsibility to protect human rights.

Considering the limitations excreted by parliament, we may say that human rights laws are properly in conformity with parliament. On the one hand, human right law has empowered the courts with a new authority to exercise the amendments easily to Supreme Court by way of parliaments; on the other hand, parliament can determine the regulations and committees to affect the human rights that were accepted by government.

The Human Rights Act 1998 provided a good opportunity for the House of Lords to play its role in protecting the human rights. Many upper chambers or Senates have special authorities to veto or scrutinize the laws that have effect on constitutional rights and freedoms. This may compensate the passive role of the parliament of England in enacting the international treaties; it means that upper parliament affirms the countries commitment to the treaties prior to government enters into any mandatory and binding international treaties (Reidy and Russell, 1999).

The Human Rights Act 1998 fade into obscurity after England left the European Union. Both groups (in favor of or against leaving the EU) have their own viewpoints. Prior to the England's Parliamentary elections, the Conservative election manifesto promised to repeal the 1998 Act and introduce British Bill of Rights (McRobie, 2016).

Although leaving EU cannot render the European Convention on Human Rights null and void, it can be abolished by parliament at any time by ratifying new laws. The European Convention on human rights was initiated by Council of Europe that is entirely separate from EU. If England officially ended the 1998 Act, the relationship between England's courts and European court of Human rights located in Strasburg will come to an end. Consequently, if any dispute rises, the judgment made by English courts will be given priority over and European Court of Human Rights.

There is no legal bill on human rights in Australia and two committees in the Senate chamber scrutinize the issues which are against human rights. (Victoria and the ACT have human rights acts). Australia does not have a Bill of Rights that applies nationally. Both committees act based on two parties' strategies. They have been successful in protecting human right of Australian citizens. The role of committees is to scrutinize the legal bills. The bills may not contain cases that are against human rights and personal freedom (Russell, 2001). 
Both committees benefit from the advisor's opinions and their weekly reports are going under the press by the Senate. Therefore, such activities make the government to perform the amendments and it plays an important role in protecting personal freedom and civil rights.

\section{Results}

The indices of second chambers' power, its arrangement and political balance prepare the ground to take the role of parliament in issues related to constitutional law into consideration. If the political space in a legislative chamber is open, it means that it is widely open to all political parties and members are actively engaged in political matters, the parliament can be considered to be powerful. The role of Senate in parliamentary systems is limited, because legislation process (especially financial laws) mainly takes place in lower chamber.

The extent to which the upper chambers are powerful depends on their combination and political balance and the role played by them in issues related to constitutional law. The second chambers differ in their elected manners, the class whom they are representative, and their effect on ratifying the bills (Russell, 2001).

So, in response to the questions proposed in the introduction, it has to be mentioned that role of the second chamber in protecting the human rights and constitutional law as well as establishing our favorite governance system based on the democracy depends on their performance and powerful actions. The factors that have effect on the power of Senate or second chambers include power of decision making, amendment of the laws, having control over and effect on the politics.

A) Decision-making accounts for an important and well-known part of the Senate legislative power. Effective Senate chambers are very active in legislature activities, but weak Senate Chambers are relatively inactive. The second chambers of the U.S senate and Italian Senate are more effective than their lower chambers (Patterson \& Mughan, 2001).

Considering the power of decision-making, the federal council of Germany is very active and strong in decision-making, and a large number of countries' governmental laws have to be scrutinized by this chamber. Almost half of the Germany's laws have to be confirmed by federal council.

More powerful and strong upper chambers are persistently active in legislating process and some other chamber is joining them. In some countries the legislating activities fluctuates widely from year to year. For example, Canada senate used to play a very active role in legislating process, but its legislating activities were considerably decreased in 1997 (Patterson \& Mughan, 2001).

B) Considering the control and supervision aspect of the senate, the England's House of Lords can be a very good example. In protecting the human rights as the main concern of this paper, the joint committee of the human rights supervises on laws and judge's performances to be compatible with 1998 human right Act based on implementation of the European convention on human rights.

C) With regard to law amendment, the amendment is considered as a crucial matter in upper chambers. For example, the senators are free to propose amendment. In Germany, upper chambers scrutinize the government laws prior to their presentation to federal council. So, the amendments proposed by upper chambers can be made in laws prior to their presentation at lower chambers (Patterson \& Mughan, 2001).

The second chamber acts as standing hindrance against changing the constitutional law in countries, in which the second chamber has effect on revising the constitutional law. The actions taken by second chamber to prevent revisions and amendment in constitutional law is highly dependent on its political balance. For example in France and Germany, the high conflicts between the two chamber, results in precise negotiations for any amendment in the constitutional law (Russell, 2001).

D) the most important role and activity of the second chambers may be their effect on politics. This role can be fulfilled by establishing a legitimate order which is compatible with constitutional law, playing the leading role in revising the constitutional law and making decision on vital issues like budget and integrity of the constitutional law (Patterson \& Mughan, 2001).

The power of second chambers results in its higher proficiency at protecting the citizens' rights, constitutional freedoms and protecting the constitutional law. Upper chambers play a variety of roles in protecting constitutional law and human rights. All of these roles have been specified and formulated in constitutional laws. The issues like human rights and constitutional law should be supported by all without prejudice. This important duty can be better performed by the upper chamber, because it investigates the issues without considering the party related matter. But the roles and nature of the second chamber will remain as a subject of long term controversies. 


\section{References}

Abbasi, B. (2015). Comparative constitutional rights (1st ed.). Tehran: Dadgostar Publication.

Blackburn, R. (1999). The House of Lords" in Constitutional Reform, Blackburn and Plant.

Boushehri, J. (2011). Constitutional rights (constitutional law of France, Swiss, England and U.S) (2nd ed.). Tehran: Sahami Enteshar Company.

Congleton, R. D. (2002). On the Merits of Bicameral Legislatures, Policy Stability within Partisan Politics. Center for Study of Public Choice.

Davis, O. M. (2003). Democratic bodies of legislature: comparative approach. Translated by Aireza Tayyeb, Tehran: Islamic Consultative Chamber research center.

Evennett, H. (2014). House of Lords, second chamber. library note.

Ghari Seyyed Fatemi, M. (2011). Human rights in contemporary world (1st Vol., 3rd ed.). Tehran: Shahre Danesh institution for legal research and studies.

Ghazi, S. A. (2001). Constitutional rights of the political bodies (7th ed.). Tehran: University of Tehran Press.

Gorji Azandaryani, A. A. (2015). Second legislative chamber: the rationale behind the establishment, background and qualifications of the Senate. Tehran: Ala Ghalam Press.

Harisi Nejad, K. (2013). Comparative constitutional rights (3rd ed.). Tabriz: Aydin Publications.

John, M. S. (1990). Considerations on Representative Government. translated by Ramin. Ali, Tehran: Nashre Ney Publication.

Madani, S. J. (2009). Comparative constitutional rights. Tehran: Jungle Publications.

Massicotte, L. (2001). Legislative unicameralism: a global survey and a few case studies. Journal of Legislative Studies, 7(1), 151-170. https://doi.org/10.1080/714003865

McRobie, H. (2016). Brexit: What it Does and Doesn't Mean for Human Rights. Retrieved from http:/wire.novaramedia.com/2016/03/brexit-what-it-does-and-doesnt-mean-for-human-rights

Norton, P. (2004). How Many Bicameral Legislatures Are There? The Journal of Legislative Studies, 10(4), 1-9. https://doi.org/10.1080/1357233042000322436

Norton, P. (2007). Adding Value-The Role of Second Chambers. Asia Pac. L. Rev., 15, 3.

Norton, P. (2013). Democratic Dialogue: Parliament and Human Rights in the United Kingdom, A. Asia Pac. L. Rev., 21, 141.

Patterson, S. C., \& Mughan, A. (2001). Fundamentals of institutional design: the functions and powers of parliamentary second chambers. Journal of Legislative Studies, 7(1), 39-60. https://doi.org/10.1080/714003851

Ranjbar. A. (2004). Iran Senate: the legal position and political performance. Tehran: the center for Islamic Revolution documents.

Rasekh. M. (2005). The theoretical base of the legislative amendment. Tehran: Islamic Consultative Chamber research center, center of legal studies.

Reidy, A. (1999). Is House of lords in defense of human rights? Constitution unit, school of public policy.

Russell, M. (2001). Responsibilities of Second Chambers: Constitutional and Human Rights Safeguards. Journal of Legislative Studies, 7(1), 61-76. https://doi.org/10.1080/714003854

Russell, M. (2010). A stronger second chamber? Assessing the impact of House of Lords reform in 1999 and the $\begin{array}{lllll}\text { lessons for } \quad \text { bicameralism. } & \text { Political } & \text { Studies, } & 586(5), & \text {. }\end{array}$ https://doi.org/10.1111/j.1467-9248.2009.00810.x

Russell, M., \& Reidy, A. (1999). Second Chambers as Constitutional Guardians and Protectors of Human Rights.

Sell, D. (2001). The history of bicameralism, second chamber. London: Frank Cass https://doi.org/10.1080/714003862

Tabatabaei Motmeni, M. (2007). Constitutional rights (overview and important political regimes) (12th ed.). Tehran: Mizan Publication. 


\section{Copyrights}

Copyright for this article is retained by the author(s), with first publication rights granted to the journal.

This is an open-access article distributed under the terms and conditions of the Creative Commons Attribution license (http://creativecommons.org/licenses/by/4.0/). 